\title{
Webarcheologie, schatgraven in en bewaren van het recente (born-)digital verleden: een praktische handleiding
}

\begin{abstract}
Once websites are no longer online and out of the reach of web archives, their preservation needs to be approached from a different angle. Ongoing access to our digital treasure chests requires immediate consideration and action. Twenty-five years ago, De Digitale Stad - a unique structure comprising computers, modems and phone cables - opened its virtual doors. This 'Digital City' is the oldest Dutch online community and plays a key role in the internet history of both Amsterdam and the Netherlands. Based on a case study entitled 'De Digitale Stad Herleeft' (The Digital City Revived), we provide answers to the following questions: (I) how do you excavate an object like the Digital City and transform it from a virtual Atlantis into a virtual Pompei, and (2) how do you reconstruct, preserve, unlock and present digital heritage material for future generations in a sustainable way.
\end{abstract}

TREFWOORDEN: webarcheologie, webarchivering, digitale preservering, internetgeschiedenis, computererfgoed, digitale geschiedenis, Amsterdam, De Digitale Stad

Introductie: 'De grond in' en graven

Het behoud van onze digitale schatkamers van het wereldwijde web en de blijvende toegang voor toekomstige generaties vereisen onze onmiddellijke zorg en actie. Zestien jaar geleden al erkende UNESCO de belangrijke historische waarde en luidde het de noodklok voor het mogelijke verlies en van ons (born-) digital erfgoed als 'unieke bronnen van de menselijke kennis en expressie.' ${ }^{\text {I }}$ Vier jaar geleden waarschuwde internetpionier Vint Cerf wederom voor een 'digital dark age': 'Humanity's first steps into the digital world could be lost to future historians. We face a forgotten generation, or even a forgotten century. ${ }^{2}$ Als we niet ingrijpen, raken we cruciale informatie over ons moderne leven kwijt. 
Als websites niet meer online zijn en zich buiten het bereik van webarchieven bevinden, moet er op een nieuwe manier onderzoek naar worden gedaan. Deze manier lijkt nog het meest op archeologisch onderzoek. Je moet het webobject eerst zien 'op te graven' en te reconstrueren. Met deze aanpak ga je verder dan het maken van een momentopname, zoals doorgaans bij webarchivering het geval is. Net als een archeoloog ga je op zoek naar sporen die met het blote oog niet te zien zijn en door traditionele historische methoden niet gevonden kunnen worden. Een voordeel van deze werkwijze is dat het publiek, na het opgraven en het reconstrueren, de oorspronkelijk werkende website idealiter weer kan bekijken en ervaren zoals die ooit online was. Net als bij reguliere archeologie moet de onderzoeker hiervoor 'de grond in' en graven in de digitale lagen. De overblijfselen, de gevonden scherven en andere artefacten, moet de webarcheoloog eerst weer in elkaar lijmen, zij moet de sporen interpreteren en de oorspronkelijke digitale toestand van object in bits en bytes zien te reconstrueren. Op deze manier verwerft de onderzoeker inzicht in de werking, het gebruik en de betekenis van het object en kan zij het verleden reconstrueren en duiden. We zien webarcheologie daarom als het digitale equivalent van archeologie.

Als het web de allerjongste kleilaag is die we ontginnen, vormen data het nieuwe aardewerk en scripts 3 de nieuwe schoppen. Webarcheologie is een nieuwe methode in e-cultuur waarbij we relatief nieuwe (born-digital) objecten, die nog niet zo lang geleden verloren leken te zijn gegaan, opgraven en reconstrueren met digitaal gereedschap. Zowel de materie als de methoden om ons digitale verleden op te graven en te reconstrueren, zijn piepjong en nog volop in ontwikkeling. In deze praktische handleiding laten we zien hoe we met digitale archeologie een digitale omgeving uit het verleden opgraven en hoe we de archeologische vondsten veiligstellen en duurzaam bewaren voor toekomstige generaties.

Om het nieuwe vakgebied vorm te geven startte het Amsterdam Museum in 20II met de eerste webarcheologische verkenningen in het project 're:DDS, de reconstructie van De Digitale Stad'. Hieruit ontstond het project 'De Digitale Stad Herleeft' in samenwerking met Waag Society, Universiteit van Amsterdam en het Nederlands Instituut voor Beeld en Geluid. ${ }^{4}$ Op dit moment worden de archeologische vondsten opgenomen in het e-depot van het Nederlands Instituut voor Beeld en Geluid.

Aan de hand van de casestudy van De Digitale Stad geven we antwoord op de vragen (I) hoe je een object als De Digitale Stad opgraaft en transformeert van een virtueel Atlantis naar een virtueel Pompeï en (2) hoe je materiaal als dat van DDS op een duurzame manier reconstrueert, bewaart, ontsluit voor en presenteert aan toekomstige generaties. ${ }^{5}$ Ons webarcheologisch project bestond uit de volgende processen: plannen, graven, reconstrueren, ontsluiten en kennis delen. In dit artikel beschrijven we per proces onze activiteiten en lichten we een aantal voorbeelden toe uit onze casus. 


\section{Plannen}

Schrijf een plan, beschrijf de doelstellingen, doe bronnenonderzoek, beschrijf het digitale object en het belang ervan, breng in kaart wat je nodig hebt, maak een plan van aanpak, stel een begroting op, zet een communicatieplatform op.

\section{Beschrijf het digitale object en het belang ervan}

Geef argumenten op basis waarvan een digitaal-erfgoed object in de collectie opgenomen zou moeten worden, zoals de artistieke of technische waarde, uniciteit en belevingswaarde en de herkomstgeschiedenis, en neem vervolgens met de eigenaar en/of contactpersoon contact op voor meer informatie. Motiveer je argumenten: Waarom is het belangrijk om dit object 'op te graven', te reconstrueren en op te nemen in de collectie? Beschrijf ook hoe dit object zich verhoudt tot de missie en visie van jouw organisatie.

\section{Onze case study: De Digitale Stad (1994-2001)}

Vijfentwintig jaar geleden verrees een uniek bouwwerk, bestaande uit computers, modems en telefoonkabels. Op I5 januari I994 opende De Digitale Stad, de eerste virtuele stad in de wereld, in Amsterdam haar virtuele poorten. Aan de wieg van de stad stonden het cultureel centrum De Balie en de Stichting Hacktic Netwerk. ${ }^{6}$ De initiatiefnemers, 'een club jonge computerfreaks', wilden een publiek toegankelijk netwerk opzetten 'om de maatschappelijke consequenties van moderne technologie voor een breed publiek duidelijk te maken'. Marleen Stikker, de eerste virtuele burgemeester van DDS en toen medewerkster van De Balie, stelde: 'Wij willen mensen op het Internet brengen die er anders nooit zouden komen. En op die manier een debat op gang brengen over de mogelijkheden van computernetwerken.'7

DDS is de oudste Nederlandse online gemeenschap en speelt een belangrijke rol in de internetgeschiedenis van Amsterdam en Nederland. Voor het eerst werd het internet (gratis) toegankelijk voor het grote publiek in Nederland. Voor veel mensen betekende de virtuele stad een eerste kennismaking met de mogelijkheden van het internet. De virtuele stad en haar inwoners brachten objecten, ideeën en tradities voort in nieuwe digitale (hybride) vormen, zoals webpagina's, nieuwsgroepen, chats, audio en video. DDS is een belangrijke en unieke historische bron over de beginjaren van het internet in Nederland en een schatkamer van digitaal erfgoed. DDS laat zien hoe bewoners zich presenteerden op het vroege web en hoe ze met elkaar omgingen, zowel cultuurhistorisch als technologisch. De virtuele stad was niet alleen een website, maar een complex, dynamisch informatiesysteem met verschillende applicaties door 
de tijd heen. DDS maakte veelal gebruik van experimentele, hybride, niet-standaard technologie. DDS volgde de nieuwe ontwikkelingen altijd op de voet, en dat resulteerde in een aantal unieke interfaces ('stadsgezichten'), zoals duidelijk wordt uit de volgende drie voorbeelden (zie Afbeelding I-3):

I994-I995: DDS I.o - I5 januari I994 (telnet/command-line interface). De metafoor van de stad kwam tot uiting in de organisatie van de interface. Er was een postkantoor (voor e-mail), openbare forums om andere bezoekers te ontmoeten, een stadhuis en een centraal station (de toegangspoort tot het internet).

I994-I995: DDS 2.0 - I5 oktober I994 (website: statische HTML). Eerste DDS website met een grafische interface, hyperlinks, tekst en plaatjes.

I995-200I: DDS 3.0 - Io juni I995 (websysteem: statische HTML en interactieve webpagina's). In de pleinen-interface heeft elk plein een eigen thema en karakter. Een plein diende als een ontmoetingsplaats voor mensen die geïnteresseerd waren in dat specifieke thema. 'Bewoners' (gebruikers) konden onder andere een eigen 'huis' bouwen (een webpagina), e-mails verzenden en ontvangen (wereldwijd!), deelnemen aan discussiegroepen, chatten in cafés en rondwandelen en meebouwen aan de 'Metro'.

\section{De Digitale Stad}

1 BELFMGRIJK: De Digitale Stad 2.0

2 Helpdesk

3 Het Postkantoor

4 Openbaar Forum

5 De Bibliotheek

6 Gebouw voor Kunst en Cul tuur

7 Het Stadhuis

8 Kantoorwijk

9 Verkiezingscentrum

10 De Kiosk

11 Een Plein

12 Universiteit van Amsterdam

13 Centraal Station

14 Configuratie-centrum

$\mathrm{x}=$ Exit h=Hoofdmenu v=Uorig Menu w=wie zijn er?

Keuze ?

Afbeelding 1. Screenshot van DDS1.0, online op 15 januari 1994. Gevonden in de opgegraven data tijdens de 'Grave Diggers Party' op 13 mei 2011. De opgegraven data bevinden zich in de collectie van het Nederlands Instituut voor Beeld en Geluid. Rechten van alle in deze bijdrage gebruikte afbeeldingen: Stichting Beheer Digitaal Erfgoed DDS (BY-NC-SA), tenzij anders vermeld in de bronvermelding. 


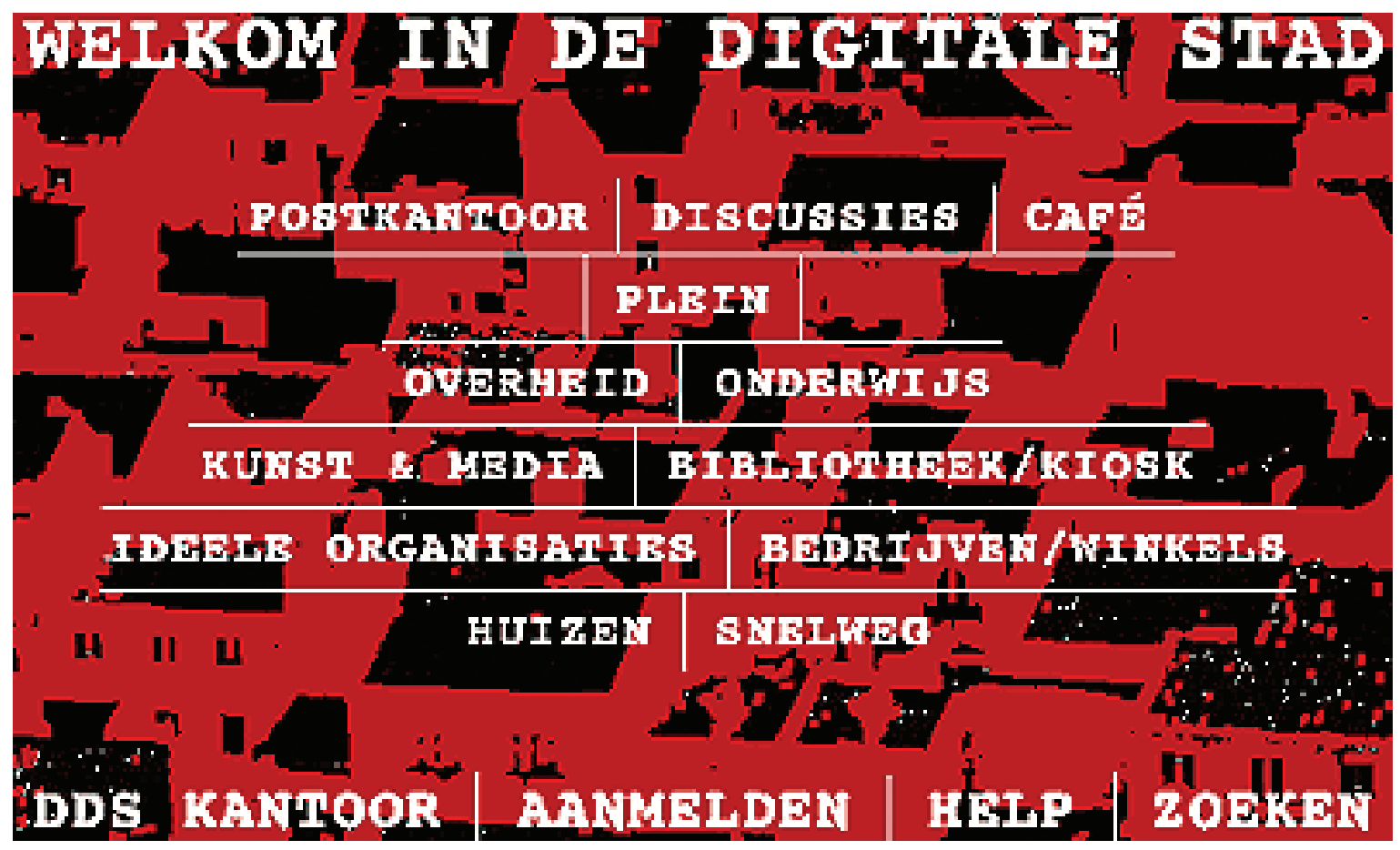

Afbeelding 2. Screenshot van DDS2.0, online op 1 oktober 1994. Gevonden in de opgegraven data tijdens de 'Grave Diggers Party' op 13 mei 2011.

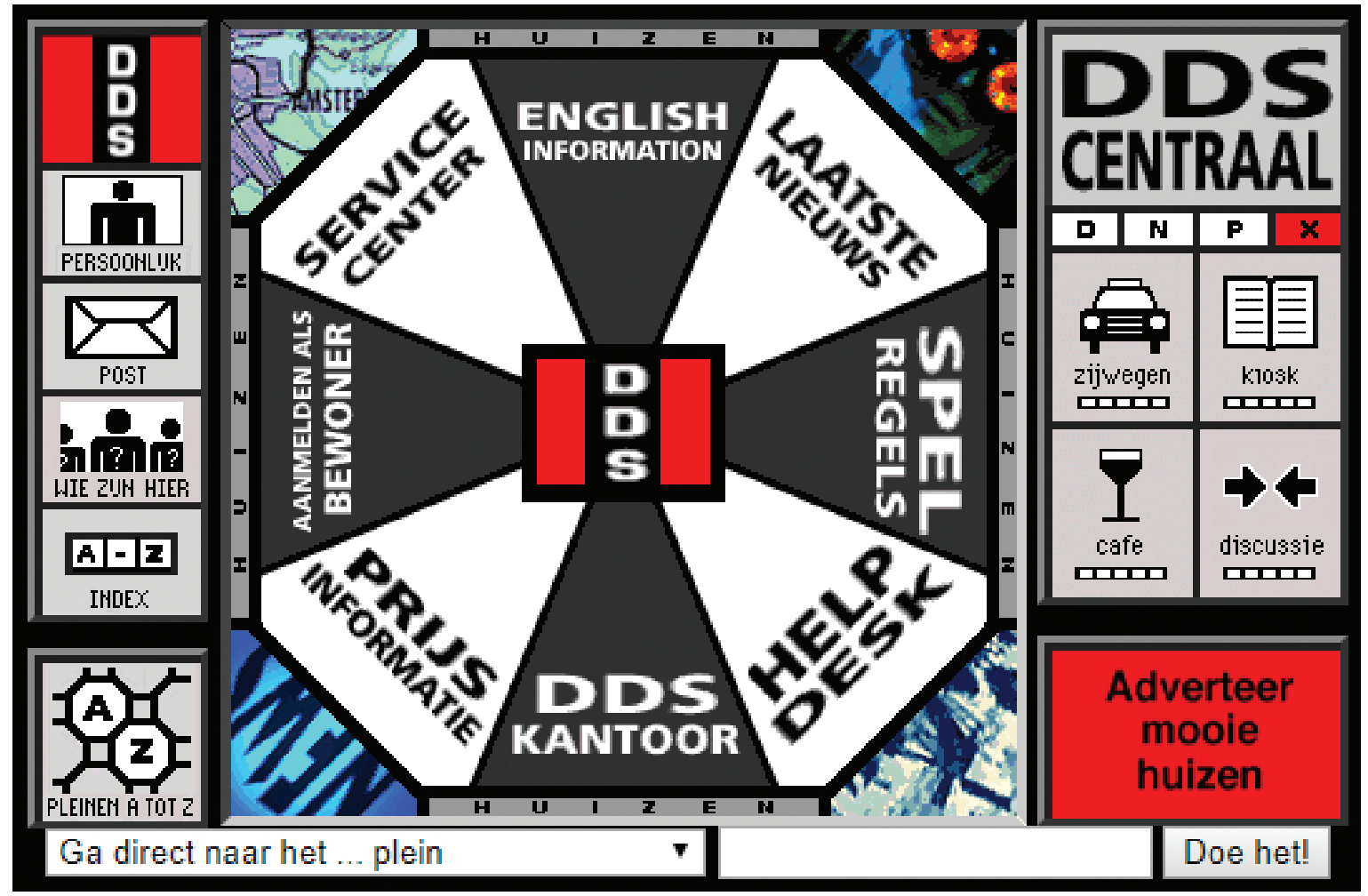

Afbeelding 3. Screenshot van DDS3.0, online op 10 juni 1995. Gevonden in de opgegraven data tijdens de 'Grave Diggers Party' op 13 mei 2011. 


\section{Graven}

Maak een inventarisatie van gewenste objecten, maak je plan wereldkundig, maak vondstkaarten, breng mensen, verhalen en objecten bij elkaar, garandeer de data-integriteit van je vondsten, stel je vondsten veilig.

\section{Breng mensen, verhalen en objecten bij elkaar}

Digitale objecten hebben te maken met ons recente verleden - waarin vele betrokkenen nog in staat zijn om hun herinneringen en inzichten te delen. Organiseer daarom bijeenkomsten om mensen te herenigen en verloren objecten en herinneringen te verzamelen. Breng oorspronkelijke bouwers, bedenkers, bezoekers en gebruikers van het digitale object samen met je team webarcheologen. Hierdoor stimuleerje kennisoverdracht en ontstaat een beter begrip over je object. Digitaal erfgoed is doorgaans complex en vergt (vooral technische) ervaring en expertise. Niet alleen hedendaagse kennis, maar juist de kennis van de historische data, software en hardware is essentieel. Samen ben je slimmer. Bovendien komen webarcheologen op deze manier misschien wel achter de vindplaats van verloren gegane digitale en fysieke artefacten.

Onze case study: De 'Grave Diggers Party'

'Help ons om deze unieke stad op te graven, kom naar de aftrap van onze webarcheologische graafwerkzaamheden en draag bij aan de restauratie van dit historisch monument! Kijk op je zolder en/of harde schijven. Breng alle servers, modembanken, VTroo-terminals, freezes, harde schijven, scripts, zips, floppies, tapes, back-ups, logbestanden, video's, foto's en screenshots die je kunt vinden en vertel ons je herinneringen en verhalen!' Met deze oproep nodigde het onderzoeksteam voormalige inwoners, oud-DDS werknemers en zielsverwanten uit voor de 'Grave Diggers Party' op vrijdag I3 mei 20II. Het was een feest om mensen te herenigen en verloren objecten en herinneringen te verzamelen.

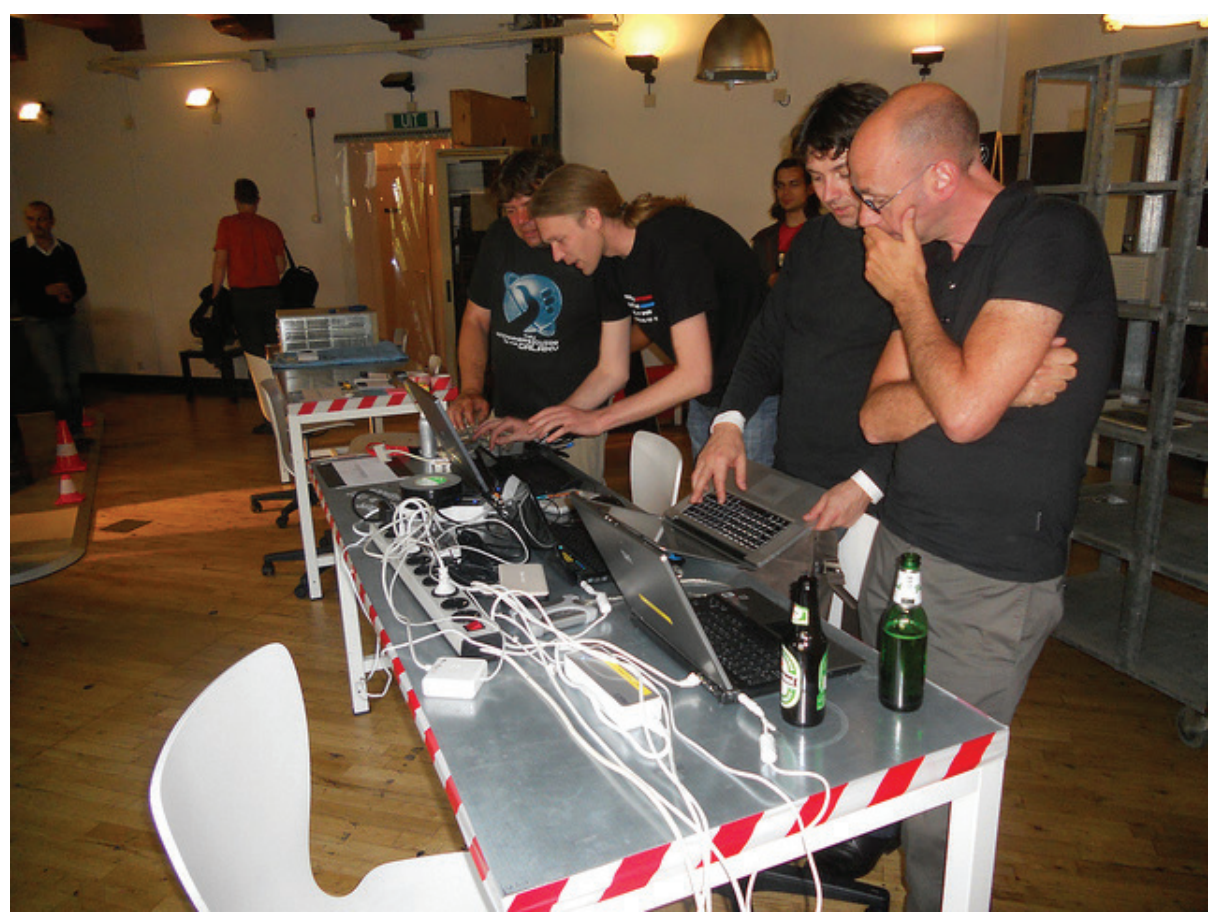

Afbeelding 4. Foto van webarcheologen op de 'Grave Diggers Party' in de Waag Society in Amsterdam op 13 mei 2011. Foto: Tjarda de Haan, 13 mei 2011. 
Gewapend met digitaal gereedschap onderzochten de webarcheologen het aangeleverde historische DDS materiaal om de geschiedenis en het gebruik van vroege computerarchitectuur, randapparatuur, besturingssystemen, programmeertalen, systeembeheer tools en dergelijke te bestuderen. Het gereedschap bestond uit computers (digitale graafmachines), opslagapparatuur (emmers), USB sticks (vondstzakken), UNIX commando's (spades, pikhouwelen, troffels) en scripts (metaaldetectoren). De webarcheologen verzamelden de gevonden voorwerpen, de (oorspronkelijke) overblijfselen van de verloren gegane virtuele stad, op een harde schijf, ínclusief de metadata.

Naast de technische werkruimte in de 'Archeologische Vindplaats' was een ruimte ingericht om deelnemers ter plekke te interviewen. We plaatsten werkstations met online toegang tot de Wayback Machine van het Internet Archive naar de DDS website met daarin de pleinen en de huizen. ${ }^{8}$ Terwijl deelnemers door de historische stad en huizen surften, door de tijd heen, bedreven we oral history om verhalen te verzamelen. Oral history is een wetenschappelijke vorm van geschiedschrijving, ontwikkeld om herinneringen van ooggetuigen vast te leggen. 9 Deze verhalen, met de kennis en ervaringen uit het verleden, zijn de handleidingen voor de toekomst. Het geheugen waarover de deelnemers beschikken staan doorgaans niet in boekjes en kunnen enorm waardevol zijn voor je project.

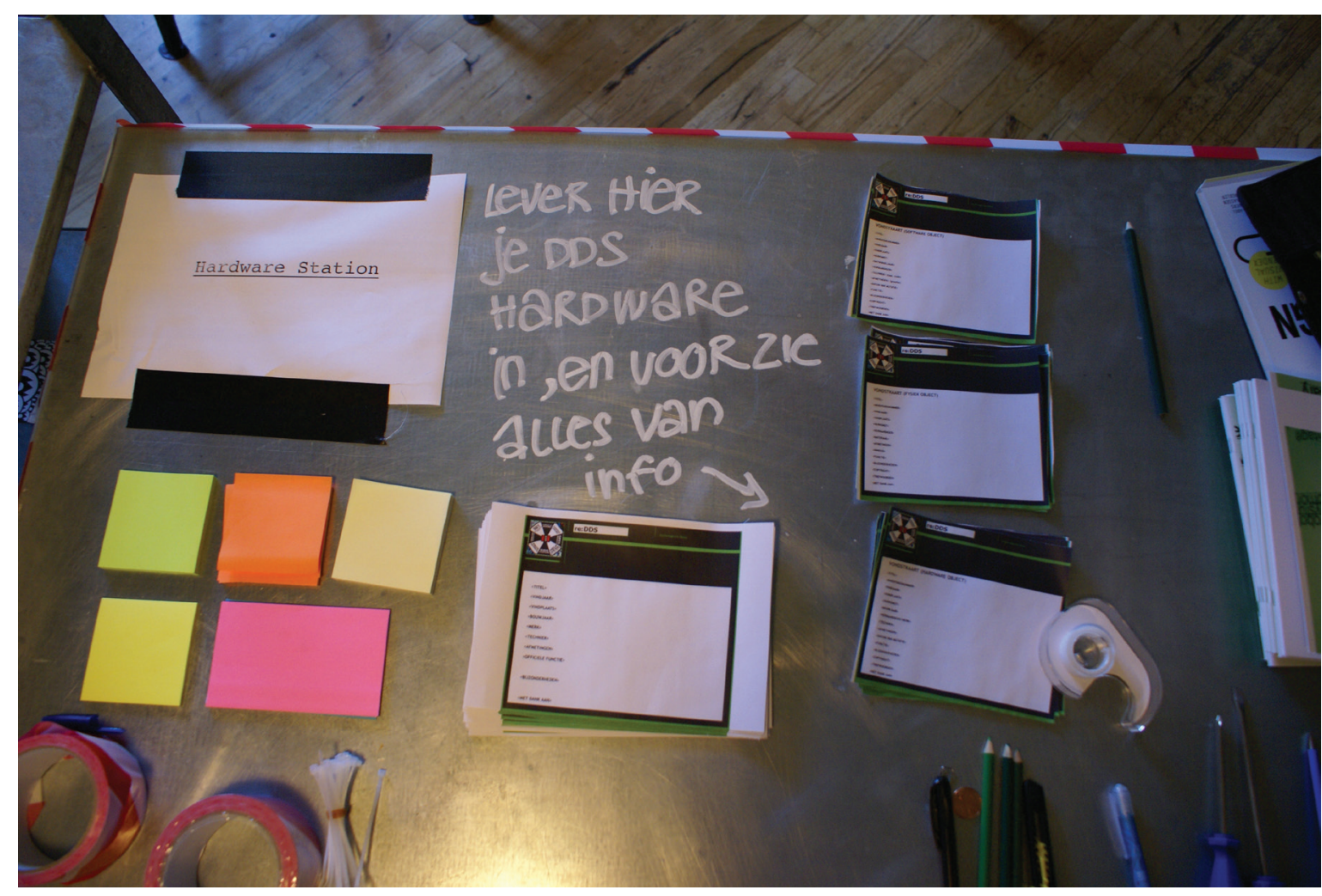

Afbeelding 5. De vondstkaarten op de 'Grave Diggers Party' in de Waag Society in Amsterdam op 13 mei 2011. Foto: Tjarda de Haan, 13 mei 2011.

Het is van groot belang om de context van de objecten (digitaal én analoog) in kaart te brengen. Gebruik vondstkaarten om de herkomst van de teruggevonden artefacten (analoog of digitaal) te documenteren. Hierdoor weet je wie het materiaal heeft ingebracht, waar het vandaan kwam, hoe het origineel werd gebruikt, wat de huidige staat van de objecten is en wie je kunt benaderen voor meer informatie, mocht dat nodig zijn. 


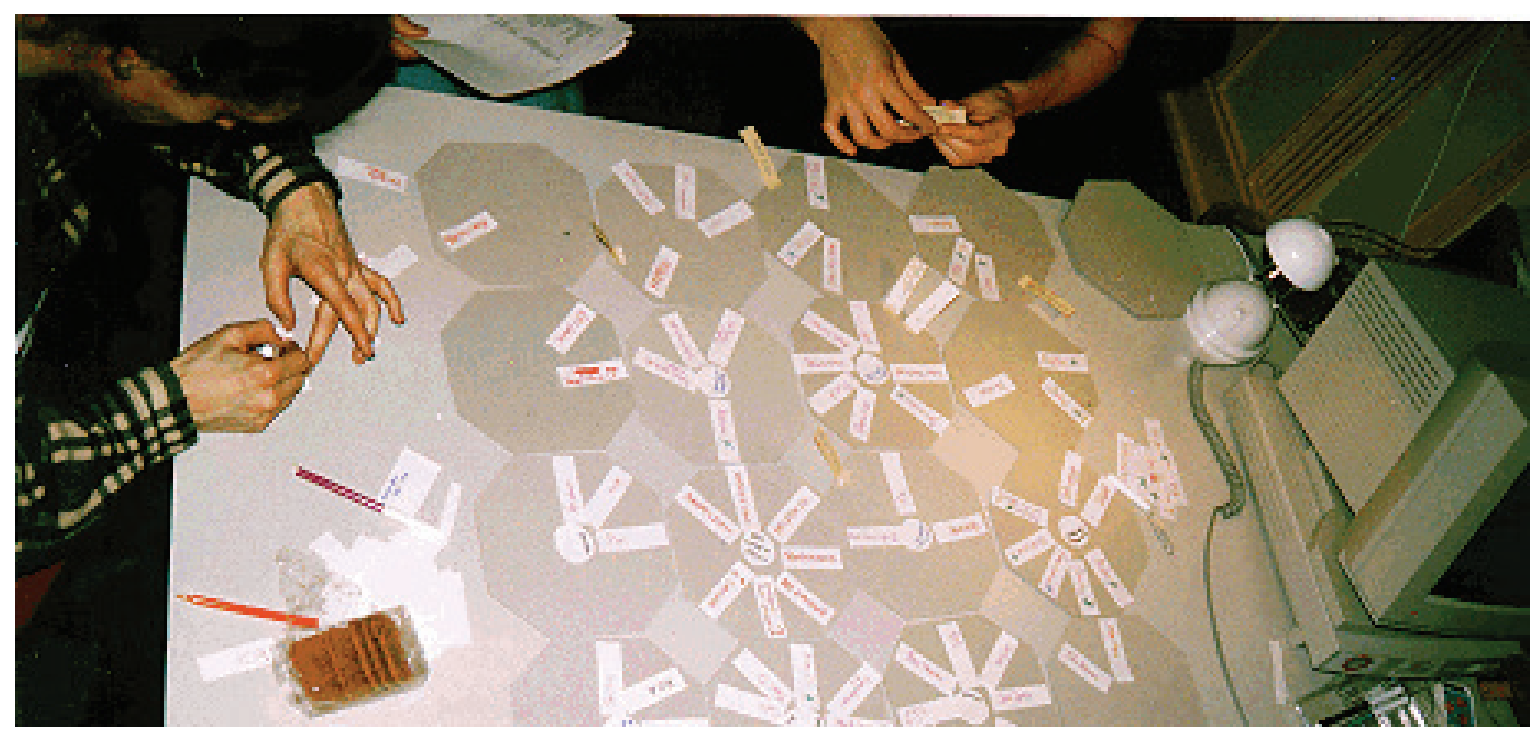

Afbeelding 6. Ontwerpers aan de slag met het maken van een papieren prototype van DDS3.0. Deze foto is op het web gevonden tijdens de 'Grave Diggers Party' op 13 mei 2011. De oorspronkelijke ontwerpers in 1995 kozen voor een iteratief ontwerpproces om de nieuwe Digitale Stad vorm te geven. Drie avonden lang heeft de toenmalige projectgroep gepuzzeld met een dertigtal kartonnen achthoeken en een grote doos stickers met daarop de namen van de informatieaanbieders (de 'pleinen'). Foto: Rob van der Haar, 22 mei 1995. ${ }^{\text {Io }}$

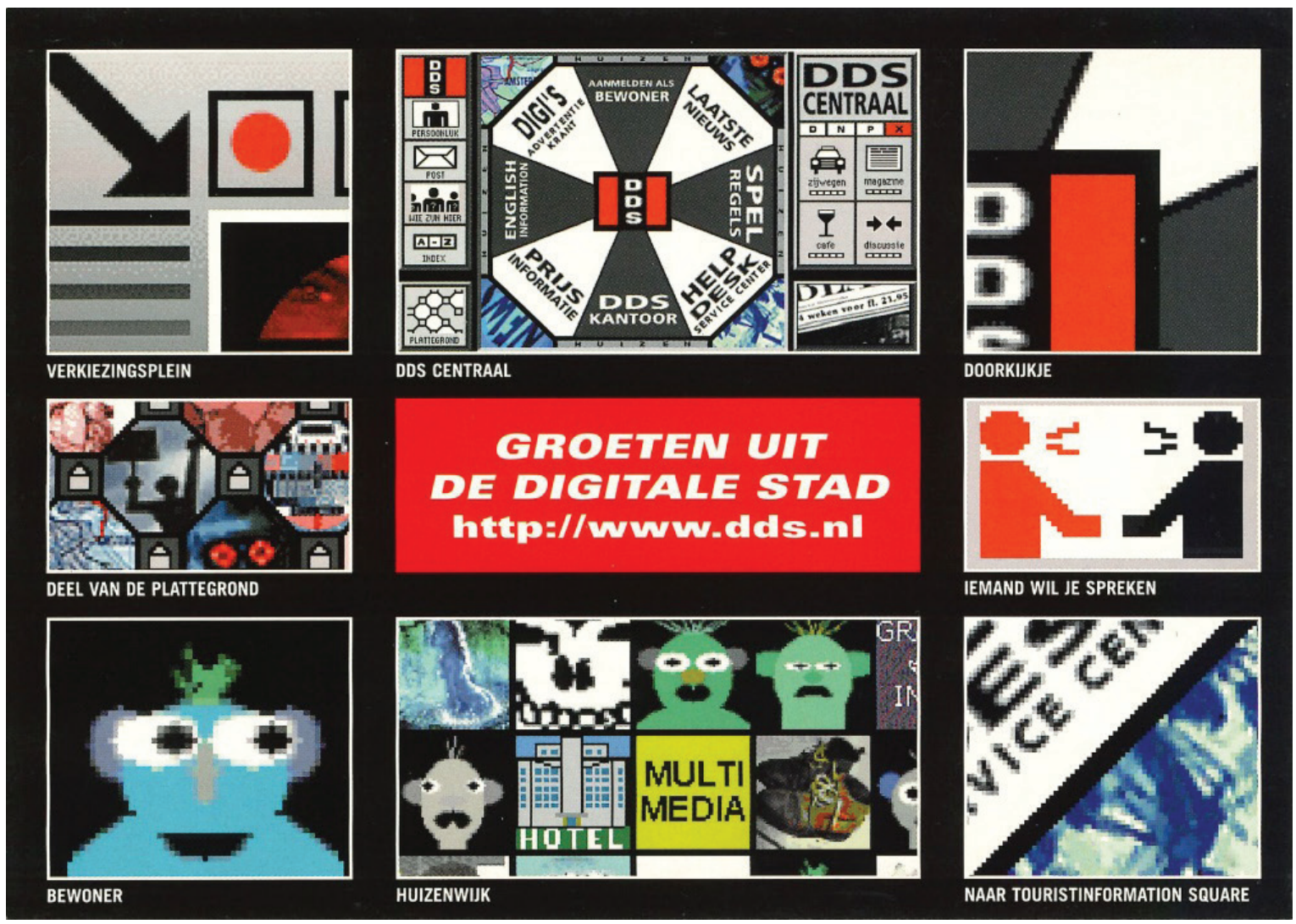

Afbeelding 7. Ansichtkaart uit De Digitale Stad, een fysieke vondst tijdens 'graafwerkzaamheden' op de 'Grave Diggers Party' op 13 mei 2011. 


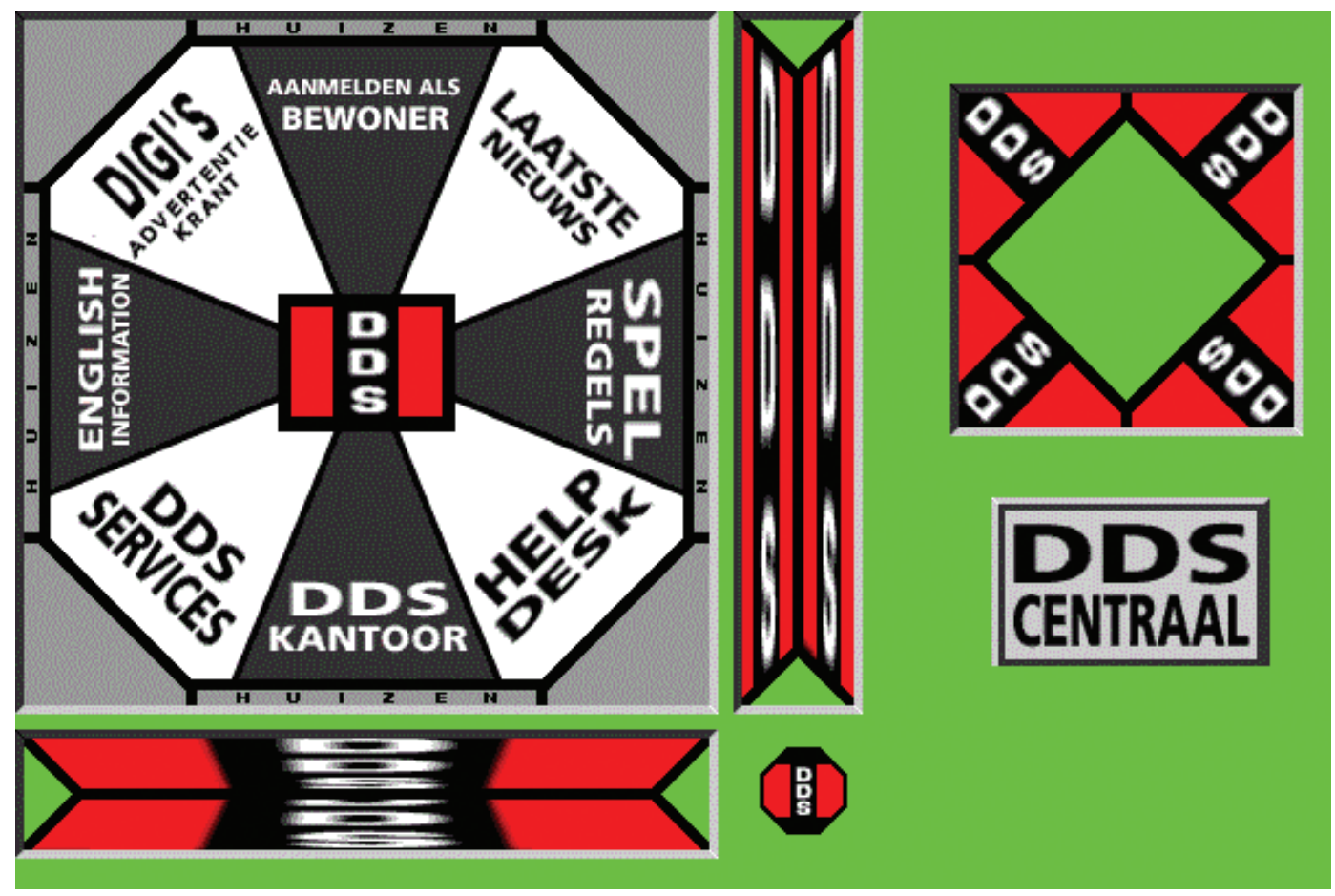

Afbeelding 8. 'Bouwplaat voor het plein DDS Centraal.' Dit grafische ontwerp is gevonden in de opgegraven data tijdens de 'Grave Diggers Party' op 13 mei 2011.

Onze case study: De FREEZE!

Naar aanleiding van de 'Grave Diggers Party' kregen we een unieke vondst in handen. Joost Flint, voormalig directeur van DDS, vond drie DLT-tapes ${ }^{\mathrm{II}}$, 'alibaba freeze', 'SHAMAN (FREEZ)' en 'dds freeze', en gaf ons deze in bruikleen voor onderzoek. Samen vormen de tapes 'De FREEZE', waar we naarstig op naar zoek waren. Op I5 januari I996 bestond DDS precies twee jaar. Voor de tweede verjaardag toonden de DDS-pioniers hun vooruitziende blik. Ze ‘bevroren’ DDS en stuurden deze als flessenpost de toekomst in. Hiermee archiveerden ze hun eigen geschiedenis. Ze beschreven en beargumenteerden hun verjaardagscadeau als volgt:

Drie versies van De Digitale Stad zijn er al geweest in twee jaar. Mensen komen en gaan. Trends komen op en verdwijnen weer. Huizen worden opgetuigd en verfraaid. Maar waar blijven alle digitale data? Wie weet over 5 jaar nog hoe DDS 3.0 eruit zag?

De Digitale Stad zal op maandag I5 januari om I8.00 precies 'bevroren' worden. Een momentopname, exact met alles wat de stad te bieden heeft zal tussen I8.00 en 9.00 de volgende ochtend worden opgeslagen op schijf en hermetisch worden verpakt. De schijven met data, samen met een complete beschrijving van de programma's en machines waarop de DDS nu draait zal worden gedeponeerd in een archief ter bestudering voor archeologen in een verre toekomst. 


\begin{tabular}{|c|c|c|c|}
\hline Wadyadingatine & 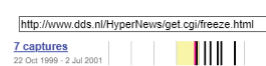 & 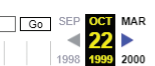 & (1) (-) \& \\
\hline
\end{tabular}

\section{De Digitale Stad bestaat (bijna) twee jaar}

Bewonersbijeenkomst 13 januari | Receptie 15 januari| De Freeze | Kroniekschrijvers gezocht! |Bewoners bijdragen Dit is een HyperNews-pagina. Je kunt onderaan de pagina commentaar leveren De verjaardag van De Digitale Stad

\section{De FREEZE}

Op 15 januari 1996 bestaat De Digitale Stad precies twee jaar.
In de afgelopen twee jaar is De Digitale Stad vooral gericht geweest op de toekomst. Deze verjaardag is een goed In de afgelopen twee jaar is De Digitale Stad vooral gericht geveest op de toekomst. Deze verjaardag is een goed
moment om eens stil te staan bij wat er de afgelopen twee jaar gebeurd is in de stad. Spraakmakende discussies, mootscheepse stadsuitbreidingen, komende en gande bewoners, vriendschapp
Digitale Stad heeft al een hele geschiedenis.
De Digitale Stad nodigt iedereen uit voor een par feestelijke gebeurtenissen:

\section{Bewonersbijeenkomst 13 januari}

Zaterdag 13 januari van 16.00 tot 18.00 uur is er in Cultureel Centrum De Balie in Amsterdam een

Een middag voor nostalgische verhalen over de oude Digitale Stad, en een discussie over het heden en de toekomst

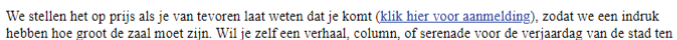
hebben hoe groot de zaal moet zijin. Wil je zelf een verhaal, column, of serenade voor de verjaardag van de stad ten
gehore brengen, vermeld dat in je e-mailtie.

De Balie

kleine Gartmanplantsoen 10

Amsterdam
(bij het Leidseplein)

Receptie 15 januari

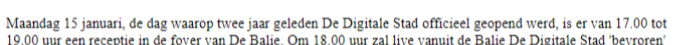
19.00 uur een receptie in de foyer van De Balie. Om 18.00 uur zal live vanuit de Balie De Digitale Stad 'bevroren'
worden (zie verderop).

Drie versies van De Digitale Stad zijn er al geweest in twee jaar. Mensen komen en gaan. Trends komen op en

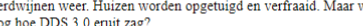

De Digitale Stad zal op maandag 15 januari om 18.00 precies 'berroren' worden. Een momentopname, exact met alles
wat de stad te bieden heeft zal tussen 18.0 en 9.00 de volgende ochtend worden opgeslagen op schiif en hermetisch wat de stad te bieden heeft $z$ al tussen 18.00 en 9.00 de volgende ochtend worden opgeslagen op schiff en hermeti
worden verpakt. De schiven met data, samen met een complete beschrijving van de programma's en machines waarop de DDS nu draait zal worden gedeponeerd in een archief ter bestudering voor archeologen in een verr

De FREEZE zal alleen de publieke informatie bevatten, geen prive-gegevens van gebruikers

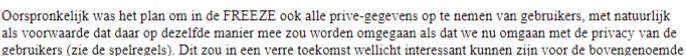
gebruikers (zie de spelregels). Dit zou in een verre toekomst wellicht interessant kunnen zijn voor de bovengenoemde
archeologen van de toekomst. We hebben daar toch van afgezien, na de reacties op deze pagina, in dds.dds en tijdens

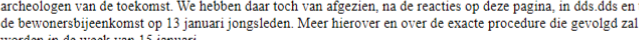
vorden in de week van 15 januari

Kroniekschrijvers gezocht!

Terviji de FREEZE een objectieve momentopname is, willen we graag ook een geschiedenis van de digitale stad. De geschiedenis van De Digitale Stad bestaat uit ervaringen, herinneringen en mythen van bewoners. Wij roepen

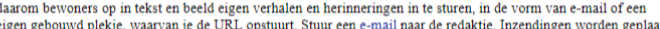

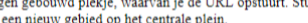

- Verhalen over je favoriete plek in de digitale stad,

: Beschrijvingen van markanten DDS-bewoners,
Herinneringen aan bijzondere gebeurtenissen

- Herinneringen aan bijzondere gebeur
Je eigen geschiedenis als bewoner?

Bewoners schrijven

De verhalen die worden opgesturd zijn het begin van de geschiedschrijving van De Digitale Stad De $O$ pkamer, literair magazine, maakte voor de freeze een eigen geschiedenis

Een Metro-verhaal, geschreven door: HJ.H.F Faas.

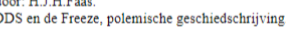

Van nepruzies naar neturienden Hein van Meeteren

Afbeelding 9. Screenshot van het artikel "De Digitale Stad bestaat (bijna) twee jaar", gevonden via de Wayback Machine van het Internet Archive. Het onderzoeksteam had van het bestaan van dit artikel over de aankondiging van het maken van 'De FREEZE', gehoord van deelnemers op de 'Grave Diggers Party'. ${ }^{\text {I2 }}$

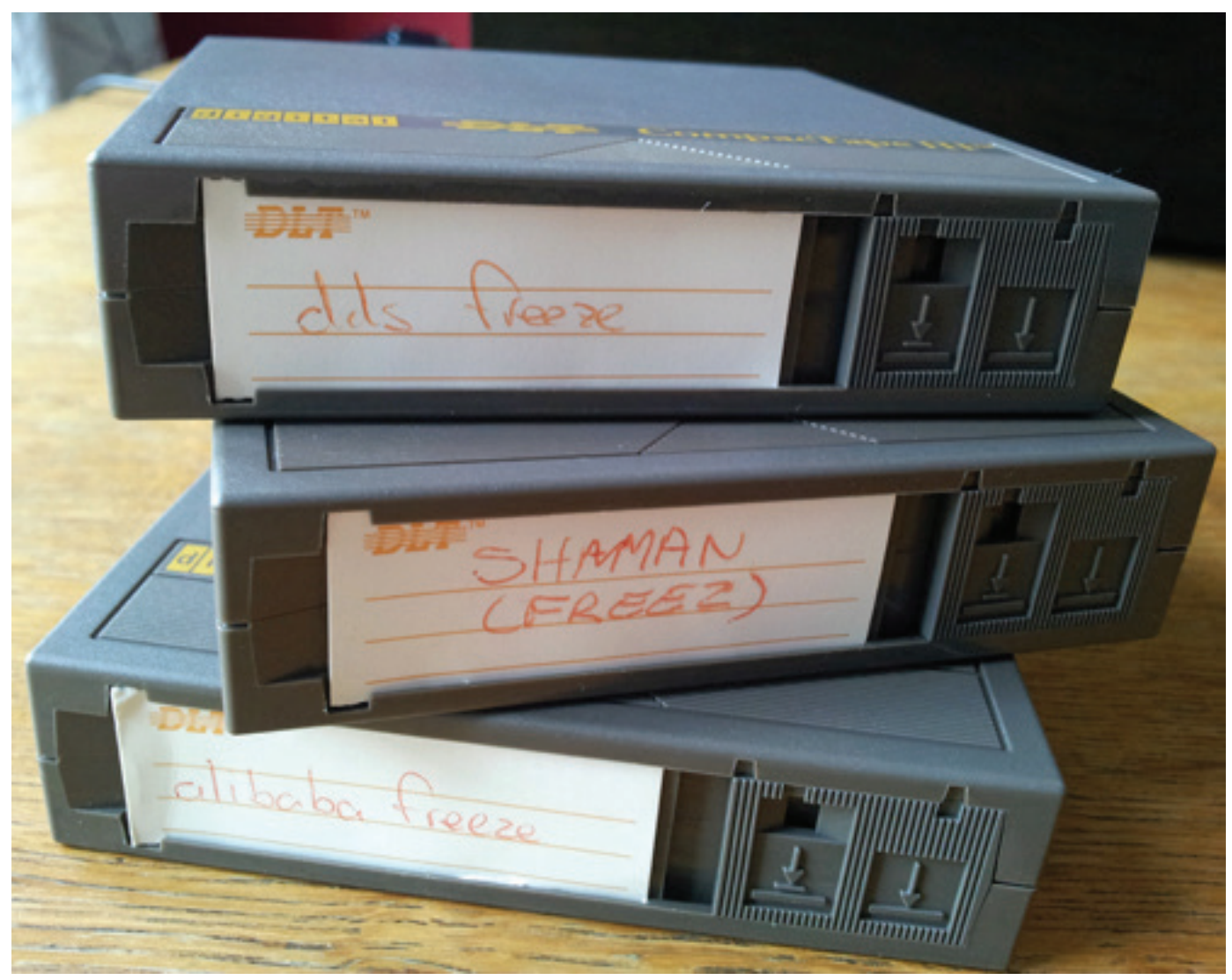

Afbeelding 10. Foto van 'De FREEZE'-tapes, fysieke opgravingen uit 2012. Foto: Tjarda de Haan, 14 maart 2012. 


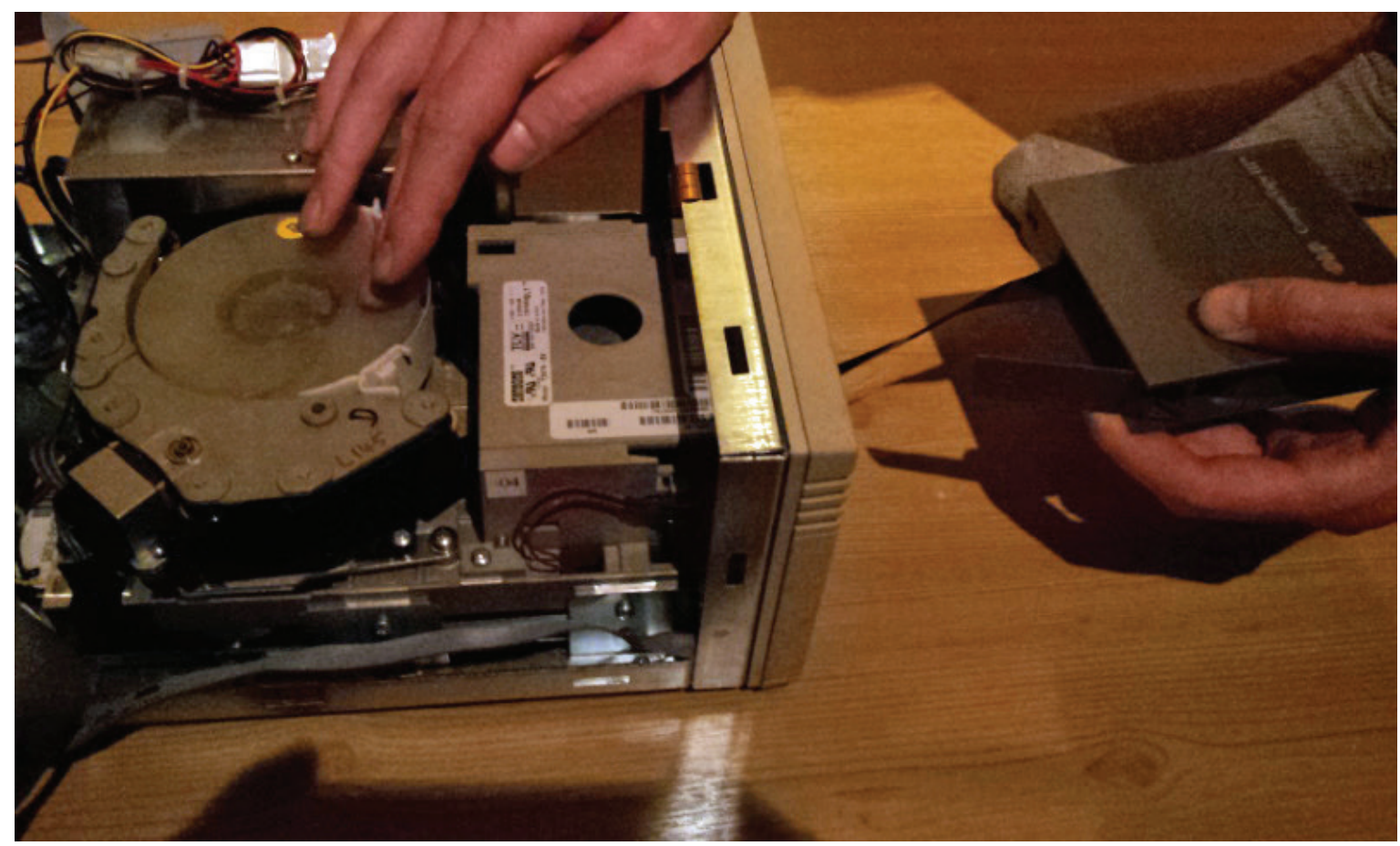

Afbeelding 11. Foto van het uitlezen van data: de praktijk van een webarcheoloog in 2012. Foto: Tjarda de Haan, 14 maart 2012.

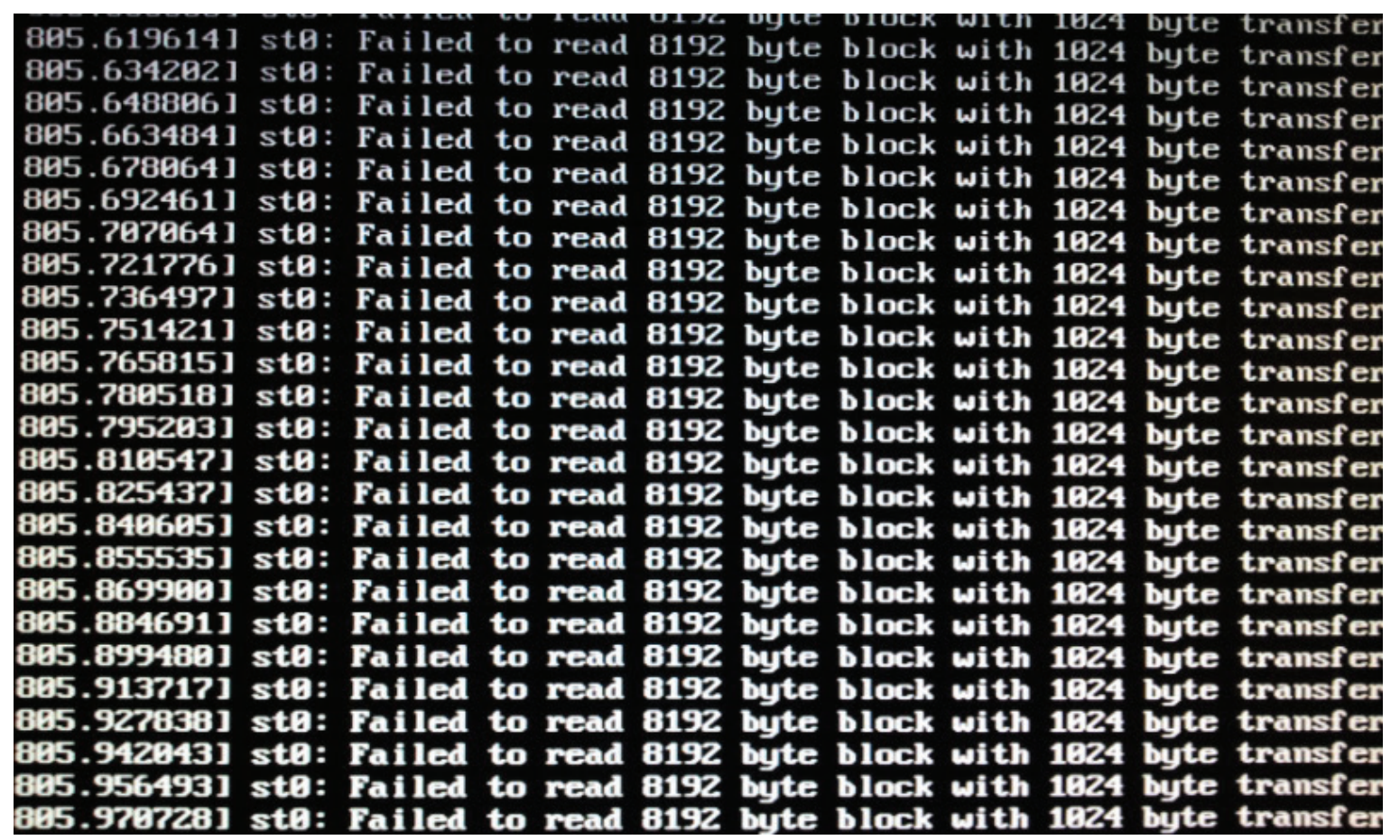

Afbeelding 12. Foto van het uitlezen van De FREEZE data: de praktijk van een webarcheoloog in 2012: 'Failed to read'. Foto: Tjarda de Haan, 14 maart 2012. 
Na onze eigen mislukte pogingen de tapes uit te lezen en bloedstollende 'reverse engineering'13 ervaringen was het uiteindelijk de technicus van het Computermuseum van de Universiteit van Amsterdam die de data van de tapes kon aflezen. Deze data vormden de bouwstenen voor de reconstructie.

\section{Reconstrueren}

Beschrijfde uitgangspunten, onderzoek de ethische kwesties, start met devoorbereidendewerkzaamheden, reconstrueer: emuleren of restaureren? Duid de data.

\section{Beschrijf de uitgangspunten}

Stel uitgangspunten op om richting te geven aan de zoektocht in de opgegraven en veiliggestelde data, en om een kader te bieden aan de hand waarvan het webarcheologische team kan gaan reconstrueren.

Onze case study: Spanningsveld 'historisch getrouw' en 'quick \& dirty'

DDS is een aansprekend voorbeeld van vroege internetgeschiedenis. Door de verschillende varianten van de virtuele stad werkend te laten zien, maak je het mogelijk dat mensen de ontwikkeling van het internet en de enorme sprongen die deze ontwikkeling heeft doorgemaakt kunnen ervaren.

Onze uitgangspunten: Het restaureren, conserveren, behouden en presenteren van digitale objecten zijn nieuwe en belangrijke taken van erfgoedinstellingen. Het reconstrueren en duurzaam ontsluiten van (born-)digital objecten stelt andere eisen dan fysieke objecten dat doen. Hoe pak je dit aan? Hoe zorg je ervoor dat bedreigde of verloren gegane digitale objecten (weer) beschikbaar worden en blijven voor erfgoedinstellingen?

Door het digitale object weer werkend te maken kan het publiek weer door De Digitale Stad wandelen en de evolutie van deze unieke virtuele stad en het vroege web ervaren en (her) beleven. Hoe kun je de oorspronkelijke gebruikerservaring weer terugbrengen? Hoe repareer je dynamische webobjecten die interactief, vernetwerkt, procesgericht en contextafhankelijk zijn? Hoe reconstrueer je historische data in het spanningsveld tussen 'historisch getrouw' (authentiek) zijn en doen wat haalbaar is binnen de mogelijkheden ('quick \& dirty')?

Als webarcheoloog ben je verantwoordelijk voor de juridische en ethische aspecten. Hoe ga je onder andere om met de privacy van de gebruikers van toen? (Let wel: het web is nog jong, de meeste betrokkenen leven nog!)

\section{Reconstrueer: emuleren of restaureren?}

Stel vast welke duurzaamheidsstrategieën jij kan/moet inzetten. Je kunt data veiligstellen door te kiezen voor een van de duurzaamheidsstrategieën: migratie, conversie, emulatie of herinterpretatie 
van de data. Of je kiest voor meerdere opties. Migratie is het verhuizen van de data naar een ander opslagmedium, conversie is het overzetten naar een ander bestandsformaat, emulatie betekent het nabootsen van een verouderde soft- en hardware-omgeving zodat oude bestanden toch bruikbaar blijven. Herinterpretatie behelst het opnieuw installeren, uitvoeren of reconstrueren van een digitaal object met nieuwe technieken. Een oorspronkelijk systeem weer werkend te krijgen heeft grote historische waarde en betekenis. Hoe 'historisch getrouw' (authentiek) je het digitale object kunt herstellen is afhankelijk van je teruggevonden data, hard-en software. Is een emulatie mogelijk? Is een restauratie noodzakelijk? Is een replicatie wenselijk? Een emulatie is bit voor bit en byte voor byte gelijk aan het origineel. Een restauratie maakt zoveel mogelijk gebruik van de originele programma's en data en past de componenten (of data) aan om het digitale object weer werkend te krijgen. Een replicatie is een geheel nieuw opgebouwd object met dezelfde functionaliteit als het origineel, al dan niet met de originele data.

Onze case study: 'De Replica' en 'De Emulatie'

Op basis van 'De FREEZE'-data werden er twee versies van de derde interface (DDS3.0) gereconstrueerd die in de toekomst worden ontsloten. De eerste versie, 'De Replica', is ontwikkeld voor een algemeen publiek, alhoewel de replica alleen in het museum en het e-depot van het Nederlands Instituut voor Beeld en Geluid toegankelijk is. De tweede versie, 'De Emulatie', is alleen toegankelijk voor voor wetenschappelijke onderzoekers via het e-depot van Beeld en Geluid. De publieke variant, 'De Replica', omvat alleen die informatie die toegankelijk was zonder in te loggen; privacygevoelige en niet-openbare data, zoals accountgegevens en e-mails, zijn niet opgenomen. Door gebruik te maken van moderne software zijn ook de beveiligingsproblemen aangepakt. De wetenschappelijke variant, 'De Emulatie', omvat wel de privacygevoelige data en heeft verouderde (historische) beveiligingsproblemen. ${ }^{\mathrm{I}}{ }^{4}$

\section{Ontsluiten}

Archiveer: statisch of dynamisch? Zoek een partner, beschrijf de gewenste preserveringsscenario's, geef toegang aan doelgroepen, documenteer, documenteer, documenteer.

\section{Beschrijf de gewenste preserveringsscenario's}

Stel preserveringsscenario's op verschillende niveaus op om de mogelijkheden, wensen en eisen van jouw instelling en de depotgever goed op elkaar af te stemmen. Als je een dynamische webomgeving wilt archiveren, voldoet het maken van momentopnames ('snapshots') niet en moet je een stap verder gaan. Bij dynamische webomgevingen focus je op de dynamiek en interactiviteit van je digitale object. Bij dynamische webarchivering bied je toegang tot (weer) werkende digitale objecten. Door de webobjecten duurzaam te archiveren houd je digitaal erfgoed toegankelijk voor toekomstige generaties. Deze nieuwe variant van preservering, het duurzaam en dynamisch archiveren, vergt de ontwikkeling van nieuwe technologie en diensten. 


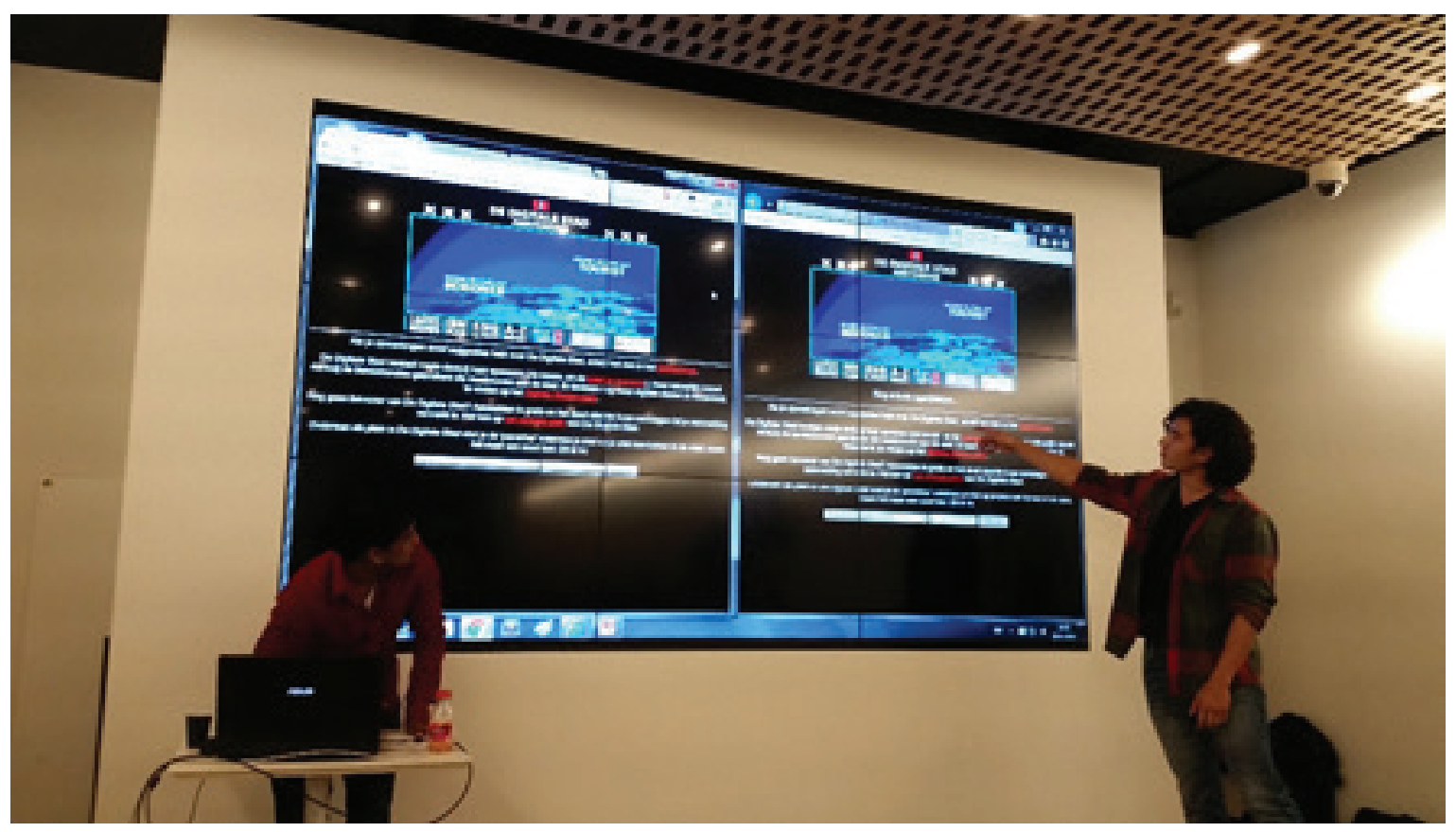

Afbeelding 13. Studenten Informatica (UvA/VU, Master of Science Computer Sciences) laten De Replica (links) en De Emulatie (rechts) zien in 2016, https://hart.amsterdam/nl/page/56068/presentaties-de-digitale-stad-gekraakt; Foto: Tjarda de Haan, 30 juni 2016.15

\section{Onze case study: DDS en het OAIS-model}

Er zijn een aantal processen waar je rekening mee moet houden om digitaal erfgoed duurzaam te bewaren en te ontsluiten in een e-depot. Zowel de aanbieder van het digitale object als de ontvanger (het e-depot) zijn hierbij betrokken. Je kunt hiervoor het OAIS-model ('Open Archive Information System') gebruiken. ${ }^{16}$ We hebben het OAIS-model als leidraad gebruikt in ons project.

Ingest: Het binnenhalen van de gegevens (digitale objecten en metadata). Hoe worden DDS data ingelezen in het archief en welke afspraken kunnen worden gemaakt?

Archival storage: Het opslaan van de digitale objecten. Op welke wijze dienen de DDS-data opgeslagen te worden?

Datamanagement: Het beheer van de metadata van de digitale objecten ten behoeve van zoek-, opvraag- en beheerfuncties en het uitvoeren van controles. Hoe dienen de DDS data beheerd te worden en welke metadata zijn er nodig hiervoor?

Administration: Het beheer van het e-depot: het coördineren van de activiteiten (diensten, services en functionaliteiten).

Preservation planning: Het monitoren van het archief. Het plannen van het duurzaam beheer van de digitale objecten. Hoe blijven de DDS-data in de toekomst toegankelijk en hoe organiseren we het beheer hiervan? Dit is de kern van het duurzaam opslaan en toegankelijk houden voor toekomstige generaties van je digitale object.

Access: Toegang geven tot digitale objecten of informatie aan gebruikers. Hoe kunnen geïnteresseerden de DDS-data bereiken?

Onze case study: Preserveringsscenario's van 'DDS Herleeft'

Het Nederlands Instituut voor Beeld en Geluid, partner in het project, voert, naast het archiveren van websites van publieke omroepen, pilots uit om de duurzame opslag van en toegang tot nieuwe 
media, games en internetcultuur te onderzoeken. Hierbinnen is de ruimte ontstaan om dynamische webcontent op meer experimentele wijze te archiveren en toegankelijk te houden. In dit kader heeft Beeld en Geluid besloten om de werkende versie van DDS3.0, en overige opgegraven DDS data, te archiveren. Samen met Beeld en Geluid zijn we uitgekomen op de volgende preserveringsscenario's:

I. Bit-preservering (niet openbaar toegankelijk, read only). Alleen opslag van de data (de bits en bytes). Je bewaart alle data die je tijdens je project hebt opgegraven, zowel in originele als bewerkte staat. Het gaat hier om het bewaren van de enen en nullen, zonder duurzaamheidsacties. Deze back-up kan in de toekomst worden gebruikt om een meer complete reconstructie te maken.

2. Duurzame en dynamische opslag (niet openbaar toegankelijk, read only, master). Om de uitgebreide en diverse DDS-collecties met dynamische (werkende) data duurzaam te bewaren is ervoor gekozen om de twee reconstructies, 'De Emulatie' en 'De Replica', op te slaan als 'virtuele machines'. Deze machines kunnen de originele software en hardware nabootsen en de gereconstrueerde objecten draaien. Virtuele machines zijn daarom ideaal als archiveringsformaat voor dynamische (werkende) digitale objecten. Om te garanderen dat de data in de toekomst ook blijven functioneren, moet het gearchiveerde digitale object met regelmaat gemonitord worden, zodat risico's en veranderingen die gevolgen kunnen hebben voor de digitale collectie tijdig worden opgemerkt, zodat de juiste maatregelen getroffen kunnen worden (preservation planning). De DDS is inmiddels opgeslagen in een RAW virtueelmachineformaat ${ }^{17}$ - omtrent de toegankelijkheid van deze data (vooralsnog enkel voor onderzoekers) worden de gepaste processen ingericht.

3. Webarchiveren (openbaar toegankelijk, read only). Op basis van de emulatie en de replica werden de opnieuw publieke DDS-webpagina's gecrawled en in het Beeld en Geluid webarchief opgenomen. Dit archief is voorlopig enkel toegankelijk voor onderzoekers.

Naast het opslaan, veiligstellen en beschrijven van de opgegraven data, vereisen de functionaliteiten van een OAIS dat goede afspraken worden gemakt omtrent de overdracht en toekomstige bruikbaarheid van het materiaal. Om dit proces in goede banen te leiden en een centraal aanspreekpunt te hebben, is de stichting 'Beheer digitaal erfgoed DDS' in het leven geroepen. ${ }^{18}$

\section{Kennis delen}

Let the Bytes Free! Beschrijf en deel jouw resultaten en bevindingen en geef aanbevelingen voor toekomstig webarcheologisch onderzoek.

\section{Beschrijf en deel jouw resultaten en bevindingen}

Voor het overdragen van je digitale object is het documenteren van alle stappen in het webarcheologische proces (plannen, graven, reconstrueren en ontsluiten) en de overdracht van je digitale erfgoed aan een e-depot van groot belang. Goede documentatie is de sleutel voor nieuwe (her)interpretaties en (re) constructies door toekomstige webarcheologen, (her)gebruik door onderzoekers en het duurzaam behoud van ons digitale erfgoed. En daarmee houd je het verleden levend voor het publiek in de toekomst. 
Onze case study: 'DIY Handboek voor Webarcheologie'

In het DIY Handboek voor Webarcheologie. Do It Yourself: Plan, graaf, reconstrueer en ontsluit! delen we onze kennis en ervaringen die we hebben opgedaan tijdens het project 'De Digitale Stad Herleeft'. Het DIY Handboek is een stap-voor-stap handleiding met praktische handvaten voor het opzetten en uitvoeren van een webarcheologisch project. Bekijk onze resultaten en meer informatie op: https://hart.amsterdam/freeze.

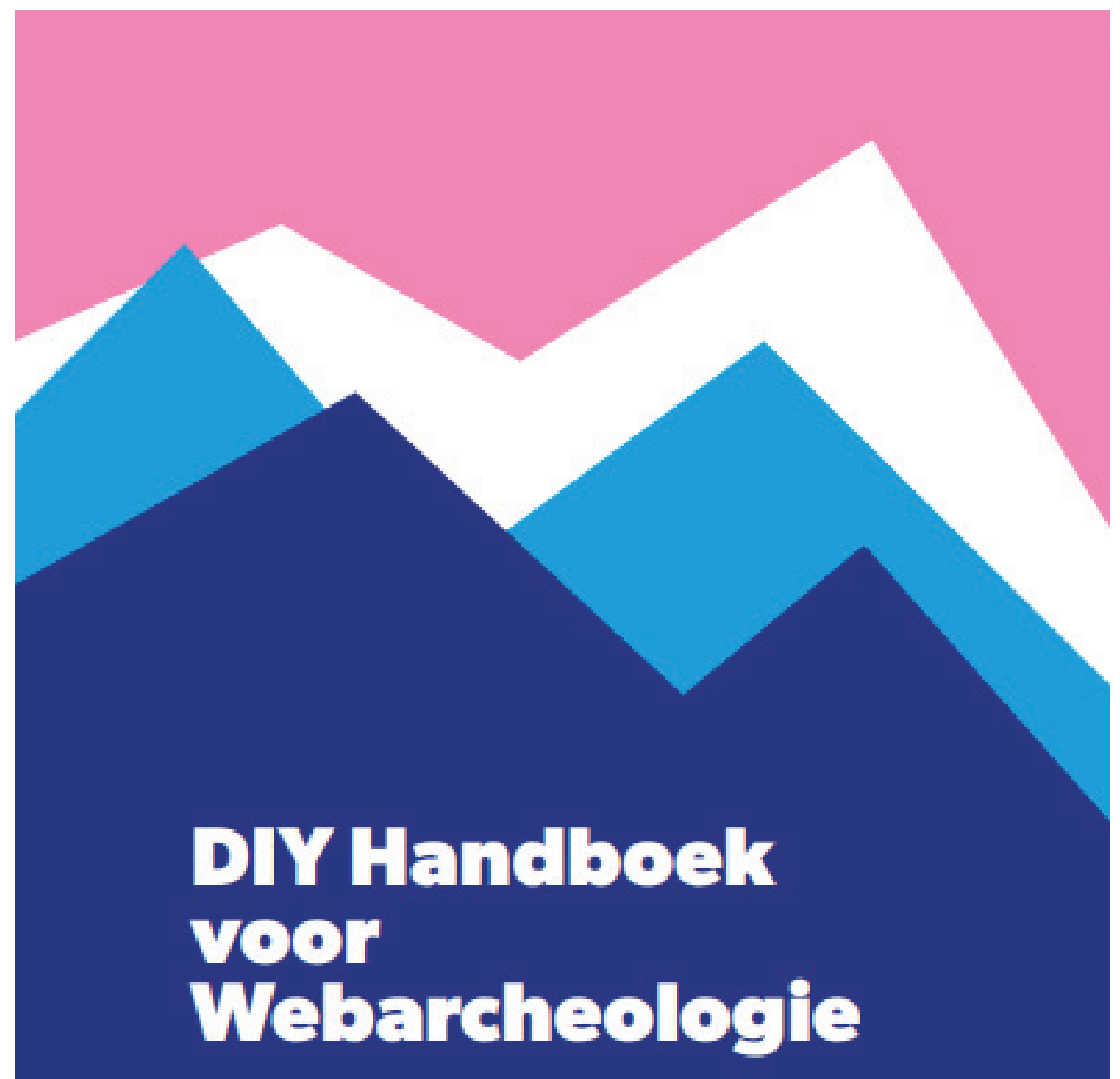

Do It Yourself: Plan, graaf, reconstrueer en ontsluit!

Auteurs: Tjarda de Haan, Robert Jansma, Paul Vogel'

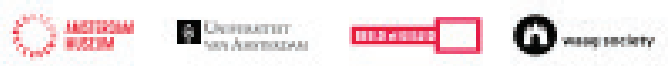

Afbeelding 14. Cover van het DIY Handboek voor Webarcheologie. Do It Yourself: Plan, graaf, reconstrueer en ontsluit!, eindpublicatie van 'DDS Herleeft' in 2017. 


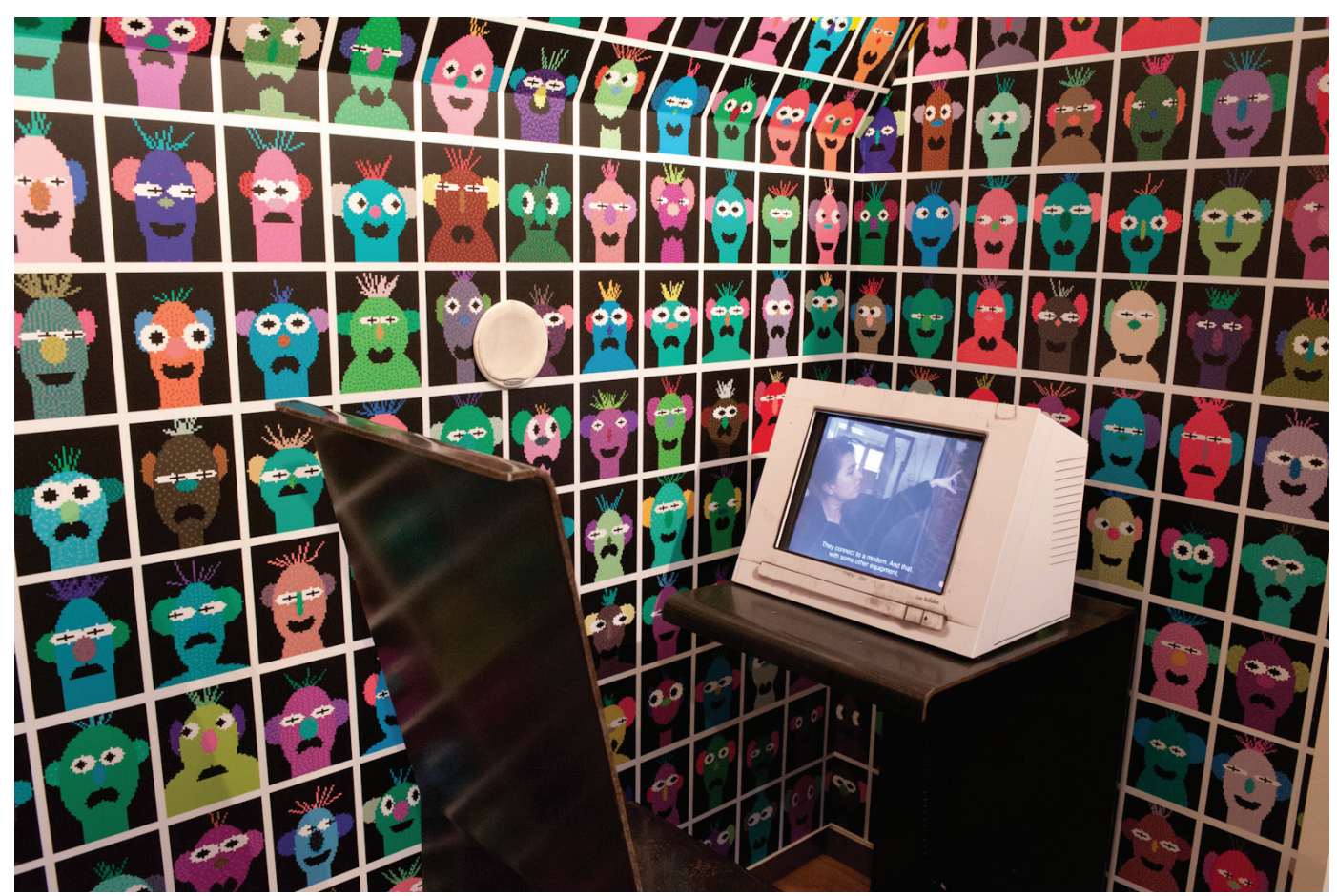

Afbeelding 15. Foto van DDS in de vaste opstelling van het Amsterdam Museum in 2014 (met één van de twee overgebleven terminals). Foto: Amsterdam Museum.

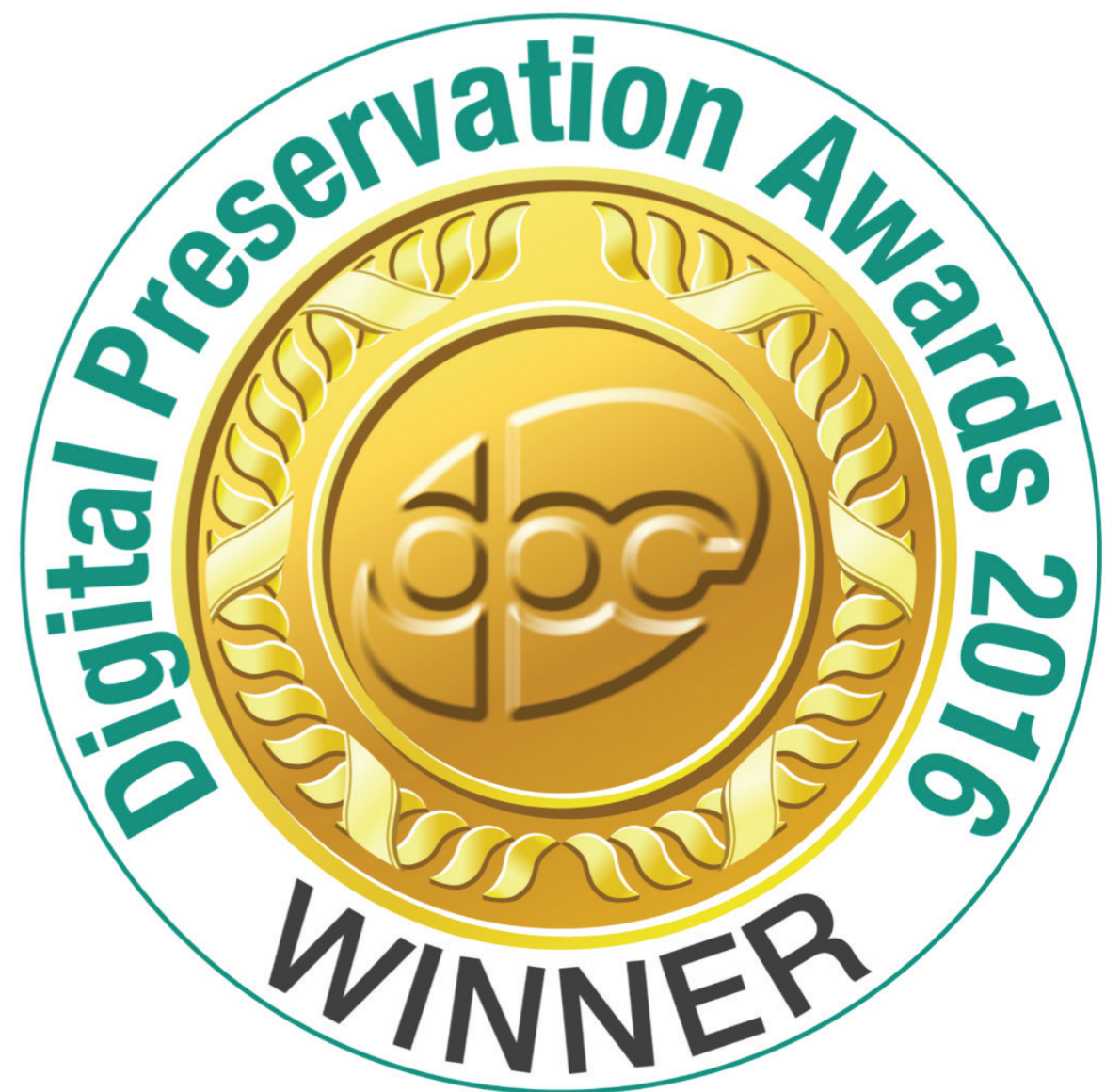

Afbeelding 16. Het project 'De Digitale Stad Herleeft' is beloond met de internationale 'Digital Preservation Award 2016'. Bron: Digital Preservation Coalition. 


\section{Conclusie}

Met het project 'De Digitale Stad Herleeft', zoals beschreven in dit artikel, heeft het onderzoeksteam een start gemaakt met het nieuwe vakgebied webarcheologie. Hiermee hopen we de drempels te verlagen voor meer webarcheologische projecten zodat we meer soortgelijk digitaal cultureel erfgoed kunnen en gaan bewaren voor de toekomstige generaties. We zijn ver gekomen, maar er liggen nog mooie uitdagingen voor toekomstige webarcheologen. Onder 'de klei' liggen nog vele schatten verscholen. Deze onontgonnen data vormen, samen met de opgegraven data, een unieke bron voor de vroege webgeschiedenis in Nederland. Ook zijn de reconstructies van DDS3.o nog niet af. Er zijn nog restauratiewerkzaamheden nodig om de stad zo dicht mogelijk bij de oorspronkelijke versie te krijgen. Tot slot zijn er, zoals bij archeologie, meerdere lagen te bestuderen: naast de kleilagen (software en hardware) zijn er cultuurlagen (data). Als straks de DDS data ontsloten zijn is het tijd voor interpretatie en duiding door de toekomstige onderzoekers zoals geesteswetenschappers en mediahistorici.

\section{Noten}

I. UNESCO, "Charter on the Preservation of Digital Heritage," http://portal.unesco.org/en/ev.php-URL_ ID=I772I\&URL_DO=DO_TOPIC\&URL_SECTION=20I.html. (Alle in de eindnoten genoemde webpagina's zijn laatst geraadpleegd op 7 juni 20I9).

2. Ian Sample, "Google Boss Warns of 'Forgotten Century' with Email and Photos at Risk," The Guardian (iz februari 2015), https://www.theguardian.com/technology/20I5/feb/13/google-boss-warns-forgotten-century-emailphotos-vint-cerf.

3. Scripts zijn kleine programmaatjes om veel voorkomende taken uit te voeren. Zoals bijvoorbeeld 'find' voor het zoeken naar bepaalde bestanden en 'grep' om in tekstbestanden te zoeken.

4. Dit project kon in 2016 en 2017 uitgevoerd worden dankzij de financiële ondersteuning van het Prins Bernhard Cultuurfonds, Stimuleringsfonds Creatieve Industrie, de Nationale Coalitie Digitale Duurzaamheid, het Netwerk Digitaal Erfgoed en het Mondriaan Fonds.

5. Deze bijdrage is gebaseerd op twee publicaties, ten eerste: DIY Handboek voor Webarcheologie. Do It Yourself: Plan, graaf, reconstrueer en ontsluit!, door Tjarda de Haan, Robert Jansma en Paul Vogel (Amsterdam, 20I7), https://hart.amsterdam/freeze. Ten tweede: “Factsheet Web Archaeology," door Tjarda de Haan, Judikje Kiers, Julia Noordegraaf, Johan Oomen en Marleen Stikker (Amsterdam, 20I7) uitgegeven door de DDS-partners en het Netwerk Digitaal Erfgoed, zie: https://www.netwerkdigitaalerfgoed.nl/kennis-en-voorzieningen/digitaalerfgoed-houdbaar/webarcheologie/.

6. Zie https://debalie.nl/ en http://www.hacktic.nl/.

7. Francisco van Jole, "De Digitale Stad van start," De Volkskrant (I5 januari I994), https://fvjole.home.xs4all.nl/ archief/artikelen/Volkskrant/ı994/dds.html.

8. Via de Wayback Machine van het Internet Archive zijn verschillende tijdsopnames ('captures'), historische varianten, van de DDS-site (http://web.archive.org/web/*/http://www.dds.nl) en van de DDS-huizen (http://web. archive.org/web/*/http://huizen.dds.nl/), te bekijken. De eerste digitale sporen dateren van 2 november I996. DDS was toen al ruim tweeëneenhalf jaar online. Tussen 2 november I996 en nu (7 juni 20I9) is http://www. dds.nl I0.204 keer gearchiveerd, en https://web.archive.org/web/20I6*/huizen.dds.nl/ 6.832 keer.

9. De getuigenissen vormden de basis voor de werkzaamheden tijdens het project 'De Digitale Stad Herleeft' en zijn verwerkt in het DIY Handboek voor Webarcheologie, zie: https://hart.amsterdam/freeze en op de website https://hart.amsterdam/re-dds.

IO. Rob van der Haar, "Projectverslag De Digitale Stad. Hacking in the polder," (22 mei I995), https://web.archive. org/web/20040II3194546/https://www.dds.nl/html/dds/jarig/3.oproject/.

II. Digital Linear Tape, een opslagmedium. Zie: https://en.wikipedia.org/wiki/Digital_Linear_Tape. 
I2. Bron: https://web.archive.org/web/19991022030349/http://www.dds.nl/HyperNews/get.cgi/freeze.html.

I3. 'Reverse engineering' is het onderzoeken van een product om de precieze interne werking ervan te achterhalen. Zie: https://nl.wikipedia.org/wiki/Reverse_engineering.

I4. Als belangstellenden 'De Emulatie' en de overige gevonden data willen bekijken, kunnen ze een verzoek indienen bij de stichting Beheer Digitaal Erfgoed DDS, bestaande uit de huidige projectpartners, die waakt over het (her)gebruik van de DDS-data. De stichting beoordeelt de aanvragen van de onderzoekers.

15. Zie voor de presentaties 'De Digitale Stad gekraakt', https://hart.amsterdam/nl/page/56068/presentaties-dedigitale-stad-gekraakt.

I6. Zie voor het OAIS-model: https://www.netwerkdigitaalerfgoed.nl/kennis-en-voorzieningen/digitaal-erfgoedhoudbaar/oais/.

I7. Een virtuele machine is een computerprogramma dat een computer nabootst, waar andere programma's op kunnen worden uitgevoerd. Door de serveromgeving waarop het DDS-materiaal werd veiliggesteld als een raw virtuele machine-formaat op te slaan, proberen we een digitaal object te creëren dat in de toekomst binnen eender welke virtuele machine-omgeving weer kan worden opgeroepen.

I8. Zie noot I3.

\section{Biografie}

Tjarda de Haan (I968, Amsterdam) werkt als webarcheoloog, digitaal erfgoed expert en webregisseur voor haar eigen bedrijf Bits and Bytes United, en als Hoofd Collecties bij Atria, kennisinstituut voor emancipatie en vrouwengeschiedenis. Zij studeerde Contemporaine geschiedenis in Amsterdam en Berlijn en werkte als gastconservator e-cultuur bij het Amsterdam Museum.

Erwin Verbruggen ( 1983 , Antwerpen) werkt als productmanager digital scholarship en kennisdeling bij het Nederlands Instituut voor Beeld en Geluid. Hij behaalde zijn mastertitel bij de UvA-opleiding Preservation and Presentation of the Moving Image, werkte als filmprogrammeur bij het Amsterdamse openluchtfilmfestival Pluk de Nacht en als archivaris bij mensenrechtenorganisatie WITNESS in Brooklyn, New York. 